\title{
Řekni, kde ti muži jsou? O chybějících mužích ve studiích reprodukce ${ }^{1}$
}

\author{
Where Have All the Men Gone? On Missing Men in the Study \\ of Reproduction
}

\author{
Ladislav Rabušic, Beatrice Chromková Manea
}

\begin{abstract}
In the context of very low to extremely low fertility levels recorded in many developed countries during the past two decades, an ongoing debate about the causes of this trend has been conducted amongst scholars and policy makers. When analyzing the results of various studies of data at either the aggregate or individual level, one important issue is worth noticing: a large number of existing analyses on the reproductive process are based largely, if not entirely, on female fertility data, whilst men are more or less absent from data gathering and analysis. In this article, we focus on male reproductive behaviour mainly in the socio-demographic context. The first part of the paper deals with an overview of the existing theoretical perspectives and research studies in which male fertility and reproductive behaviour are considered. Further, we focus on the causes of researchers' low interest in male fertility. Finally, we present an inventory of indicators on male reproduction that are employed in research and also worth considering in future investigations. The present article aims to challenge other scholars to consider and examine male reproductive behaviour in the Czech Republic.
\end{abstract}

KEYWORDS male fertility, reproductive behaviour, modelling male and female fertility, fertility indicators

\section{Úvod}

V kontextu velmi nízké až extrémně nízké plodnosti, kterou zaznamenávají mnohé vyspělé země tohoto světa, se vedou permanentní debaty o tom, jaké jsou příčiny toho, že se rodí tak malý počet dětí, který nezaručuje ani prostou reprodukci obyvatelstva. A jelikož plodnost pod úrovní prosté reprodukce má výrazné sociální a ekonomické následky, stala se nízká plodnost také problémem politickým s výraznou sociální objednávkou: nalézt příčiny (faktory), které nízkou plodnost způsobují (nebo přinejmenším ovlivňují), aby ji bylo možné ovlivňovat žádoucím způsobem.

Sociálni studia. Katedra sociologie FSS MU, 4/2011. S. 47-66. ISSN 1214-813X.

1 Napsání této statě bylo podporováno finančními prostředky projektu GAČR, č. P404/11/0329, „Reprodukční chování mužư “. Autoři upř́mně děkují dvěma anonymním recenzentům za jejich velmi cenné připomínky. 
Intenzivní demografický výzkum již pojmenoval řadu faktorů, které k tomuto stavu přispívají, ale výsledek není zcela uspokojivý. Nedaří se totiž formulovat kauzální model, který by napověděl, které faktory je třeba manipulovat k požadovanému výsledku. Celý problém navíc komplikuje fakt, že není možné úplně stavět na výsledcích zahraničních výzkumů, nebot' se ukazuje, že to, co funguje $\mathrm{v}$ jedné zemi, nemusí při srovnatelných podmínkách nutně fungovat v zemi druhé.

Hledání důvodů, proč vysvětlující modely plodnosti ne zcela fungují, přivedlo některé autory na myšlenku, že je třeba obrátit pozornost od modelů založených na agregovaných datech, ${ }^{2}$ které pracují se zprůměrovanými statistickými charakteristikami za určitou zemi, k modelům využívajícím mikrodata, což jsou individuální data získaná ze specifických sociologicko-demografických výzkumů založených na rozhovorech - at' již standardizovaných (kvantitativních) nebo hloubkových (kvalitativních).

Při studiu výsledků zkoumání založených at' na datech agregovaných, nebo na datech individuálních si není možné nevšimnout jedné podstatné věci, totiž toho, že značné množství existujících analýz reprodukčního procesu a jeho kontextů vychází pouze z údajů o ženské plodnosti a muži v těchto analýzách víceméně chybějí. Je to samozřjejmě s podivem, nebot' narození dítěte je výsledkem celé řady interakcí mezi ženou a mužem (manželem nebo partnerem), a pochopit, co vede páry k určitému počtu dětí, znamená pochopit celý dlouhodobý proces rozhodování, který tomuto výsledku předchází. $\mathrm{V}$ jeho pozadí je proces komunikace mezi mužem a ženou, jejich vyjednávání o počtu dětí a o způsobu, jak této velikosti rodiny docílit (např́klad jaké metody antikoncepce používat), vzájemné proporce dominance a submise, genderové role mužů a žen v daném kulturním kontextu apod. Je proto zřejmé, že individuální data získávaná na tato témata pouze od žen nejsou dostatečná a že pokud chceme skutečně pochopit, jak se ,plodnost dělá“, musíme do výzkumů zahrnout také muže.

$\mathrm{V}$ našem článku se proto zaměříme na mužskou reprodukci, kterou budeme sledovat především v jejím socio-demografickém kontextu. Uvedeme nejdříve některé její kontextuální atributy, poté se zamyslíme nad příčinami vedoucími k tomu, že úvahy o mužské plodnosti jsou zatím $\mathrm{v}$ analýzách reprodukce poměrně vzácné, a nakonec provedeme inventuru ukazatelů, které o mužské reprodukci máme k dispozici a které zatím chybějí. Náš text chápeme jako úvodní text (a současně i jako výzvu ostatním badatelům) ke zkoumání mužské reprodukce v České republice.

\section{Kontext mužské reprodukce}

Jak je možné, že muži v demografických analýzách chybějí? Tuto otázku si položily Greenová s Biddlecomovou (Green a Biddlecom 2000) a odpověd' shrnuly do několika důvodů. Základní př́ičinu spatřují v samotném charakteru demografie jako vědní disciplíny - demografie totiž podle nich vznikla jako účetnický systém, jako způsob číselné registrace porodů, úmrtí, stěhování a dalších populačních událostí, takže jejím cílem bylo

2 V mezinárodních srovnání se napríklad hledají vztahy mezi plodností a velikostí HDP nebo mezi plodností a indexem lidského rozvoje, mírou zaměstnanosti žen, typem sociálního státu a rodinné politiky apod. 
popsat a srovnávat populace, ne však klást si otázku typu „proč se něco děje“ (tamtéž: 82). Autorky také vidí důležitý důvod v tom, že demografické znalosti byly ovlivňovány tehdejšími sociálními normami, které spatřovaly rození dětí výlučně jako doménu ženy. Demografie považovala muže za důležitého činitele z hlediska ekonomického, jinak však do plodnosti nezasahujícího - kromě aktu oplodnění a prvku, který stojí v cestě k používání antikoncepce (tamtéž: 83). Třetím důležitým momentem byla západní kulturní (ideologická) norma, která předpokládala, že v manželství nastává souzvuk mezi zájmy muže a ženy. Manželství bylo idealizováno jako přetvoření dvou bytostí v jednu, takže potenciální prvky konfliktů a jejich vyjednávání byly záměrně přehlíženy. Pak bylo pochopitelné, že při studiu fertility stačilo zkoumat pouze jednoho z páru, nebot' tento jedinec reprezentoval pozici obou (tamtéž: 84 ). ${ }^{3}$ Podle Greenové a Biddlecomové tedy demografie absolutizovala biologickou stránku plodnosti a děti připsala pouze ženám, čímž negovala muže. Dopustila se tak velké ironie: pokud by brala své přihlášení se k biologické stránce plodnosti pevněji, musela by muže do studia plodnosti a reprodukce inkorporovat už dávno (tamtéž: 85).

Autorky mají pravdu. Pokud by demografie nebyla tak dlouho hluchá k teoriím evolučních biologů a psychologů, musela by se reprodukční rolí mužů zabývat velmi důkladně. Evolucionisté totiž opakovaně zdůrazňují, že muži a ženy jsou díky evolučnímu vývoji mentálně nastaveni k plození dětí jinak. Většina biologů zastává stanovisko, že každé chování živého organismu je výsledkem interakce mezi geny a prostředím a lidé, stejně jako organismy, mají základní snahu: přežít a reprodukovat se - a přitom maximalizovat své (sobecké) geny. ${ }^{4} \mathrm{Z}$ hlediska fertility je tedy důležitý nejen samotný počet potomků, ale také počet potomků přežívajících do věku, kdy sami produkují (rodí) další potomky. Organismy se tedy snaží o reprodukční úspěch. Ostatně ústředním pojmem evoluční biologie je, jak ve své monografii informuje Flegr (2007), pojem „zdatnosti“ (fitness), čímž se myslí souhrn tří prvků: plodnosti, životaschopnosti a sexuální zdatnosti neboli schopnosti obstát $\mathrm{v}$ procesu pohlavního výběru (to je $\mathrm{v}$ soupeření př́íslušníků stejného pohlaví o partnery $\mathrm{k}$ rozmnožování). Tyto tři prvky pak utvářejí schopnost být preferován přirozeným výběrem a zvyšovat tak frekvenci svých genů v genofondu populace (tamtéž: 46-47). Pro úvahy o biologické zdatnosti jedince je ještě důležité rozlišovat exkluzivní zdatnost (exclusive fitness) a inkluzivní zdatnost (inclusive fitness). V kontextu exkluzivní zdatnosti uvažujeme o reprodukčním úspěchu jen u samotného jedince, u inkluzivní zdatnosti se bere v úvahu jak reprodukční úspěch jedince, tak i jeho př́ibuzných $-\mathrm{z}$ hlediska evoluce je totiž jedno, zdali člověk přežije sám nebo zdali pomůže $\mathrm{k}$ přežití dvěma svým sourozencům nebo čtyřem

3 Demografové by pravděpodobně s tímto tvrzením nesouhlasili. Jak tvrdí Tomáš Kučera (ústní komunikace), demografie potřebovala přiřadit narozené (ostatně jako u všech demografických jevů) k jednoznačnému nositeli jevu - a to muži nejsou.

4 Teorii sobeckosti genů popularizoval britský zoolog Richard Dawkins v knize The Selfish Gene (1976, česky 1998). Její ústřední myšlenkou je, že živé organismy jsou pouhými nositeli genů, které mají snahu maximalizovat svůj počet $\mathrm{v}$ dalších generacích. $\mathrm{K}$ tomuto cíli pak geny rrídí (byt' velmi zprostředkovaně) aktivity těchto organismů. Tedy i aktivity člověka. 
potomkům svého sourozence (tamtéž: 50) - množství reprodukujících se genů totiž zůstává v tomto prípadě stejné. ${ }^{5}$

„Úspěšná reprodukce závisí na vyřešení dvou klíčových problémů. Prvním je volba vhodného partnera, druhým je přiměřená investice do následných potomkư“ (Barret, Dunbar a Lycett 2007: 139). Podíváme-li se z tohoto hlediska na rodinu jakožto jednotku, v níž se reprodukce tradičně odehrávala, pak zjistíme, že biologický podtext je velmi vlivným činitelem její existence. Rodina se tradičně zakládala sňatkem, který legitimizoval biologické (sexuální) spojení muže a ženy a umožňoval reprodukci. Sňatek, který není ničím jiným než hledáním vhodného partnera, se, jak nás informuje na základě své historické analýzy rodiny Stone (1979), ř́dil třemi hlavními cíli: aby byl zplozen potomek mužského pohlaví a zachovala se tak mužská linie, aby byl zachován zděděný majetek a aby se sňatkem majetek rozmnožil nebo aby se navázalo užitečné politické (sociální) spojenectví (tamtéž: 37). Z pohledu evolučního jsou všechny tři prvky částí jasného celku: v podmínkách, kdy smrt byla přirozenou součástí života (dětská a kojenecká úmrtnost, ale i úmrtnost v dospělém věku byla až do počátku 19. století velmi vysoká), bylo nesmírně důležité vytvořit v rámci rodiny podmínky pro exkluzivní zdatnost, tedy pro další rozmnožování.

Ve světě zvířat se samčí a samičí plodnost liší. Všechny samice v populaci daného druhu mívají zpravidla přibližně stejný počet potomků, avšak mezi samci existují v počtu potomků mnohdy značné rozdíly (Flegr 2007: 314). Příčinou je sociální postavení ve skupině, které ovlivňuje přístup ke zdrojům, a ten dále ovlivňuje biologickou zdatnost. ${ }^{6}$ Samci s nejvyšším statusem se totiž u mnoha druhů stávají otci převážné většiny mlád'at v dané populaci.

I ve světě lidí by se teoreticky počet potomků u mužů a u žen mohl lišit. Příčiny jsou biologické a kulturní. Biologie v nás určuje, že ženská plodnost je jasně věkově ohraničena. Schopnost rodit děti začíná kolem 15. roku a končí obvykle mezi 45.-50. rokem, takže obvykle netrvá déle než 35 let. Mužská plodnost nemá horní věkovou hranici pevně ustanovenou - při dobrém zdraví jsou muži schopni sexuální aktivity (a tudíž i reprodukce) do 70-80 let. Tento fakt vymezuje pro reprodukční potence mužů a žen značně odlišná pole. Počítejte s námi. I při stř́zlivém předpokladu, že muž je schopen zvládnout čtyři početí do měsíce (tedy jedno oplodnění týdně) a že realizuje svou plodnost 45 let (to je mezi 20-65 roky věku), může počít celkem $4 * 12 * 45=2160$ dětí. Jak ale všichni dobře víme, průměrný muž naplní z tohoto obrovského potenciálu pouze nepatrný zlomek - ve vyspělých zemích to jsou v průměru méně než dvě děti.

Důvod je opět fyziologický. Mužská plodnost není možná bez plodnosti ženské a ženská plodnost je limitována zcela jednoznačně: žena je sice plodná asi 35 roků, ale i v tomto období je po určitou dobu přirozeně sterilní, což její plodnost dále snižuje: a) ženskému organismu určitou dobu trvá, než při pravidelném nechráněném sexuálním styku k početí

5 V tomto genetickém principu tkví mimo jiné také vysvětlení altruistického chování, nebot' organismus ,může za určitých podmínek zvyšovat svou biologickou zdatnost jak produkováním většího množství potomstva, tak tím, že bude pomáhat svým př́buzným“ (Flegr 2007: 50).

6 „Mezi př́slušníky stejného druhu [...] probíhá neustálý evoluční zápas, při němž jednotlivci využívají různé strategie, které jim mají pomoci získat určitou výhodu na úkor ostatních“ (Flegr 2007: 324). 
dojde - odhady hovoří o průměru sedmi až osmi měsíců ${ }^{7}$-, což prodlužuje délku intervalu mezi porody; b) svou roli sehrává také spontánní potratovost (mnohdy vnímaná pouze jako zpoždění menstruace), což přidává k meziporodnímu intervalu v průměru dva měsíce; c) připočteme-li k tomu ještě devět měsíců od početí do porodu; a d) zahrneme-li také dobu kojení způsobující další dočasnou sterilitu ženy, která se ve vyspělých zemích pohybuje kolem pěti měsíců, zjistíme, že přirozená sterilita mezi jednotlivými porody trvá v průměru 24 měsíců. $\mathrm{Z}$ těchto čistě fyziologických důvodů je plodnost žen výrazně limitována. Ze studie o náboženské skupině Hutteritů, jejíž členové se reprodukovali v režimu přirozené plodnosti, ${ }^{8}$ víme, že průměrná velikost hutteritské rodiny byla málo přes deset dětí (Eaton a Meyer 1954). Eaton a Mayer stanovili plodnost hutteritek jako demografický standard a odhadli, že plodnost žen může dosáhnout maximálně dvanácti až čtrnácti dětí.

Počty potomků jsou ale ovlivňovány i kulturně, tedy normami určujícími, kolik reprodukčních partnerství je možné navázat. Záleží totiž na tom, zdali se reprodukce děje v monogamní nebo polygamní společnosti. Ve striktně monogamních společnostech by se muži v počtu potomků neměli lišit (za předpokladu, že budou mít stejné preference) a stejné by to mělo být i u žen. V polygynních kulturách, v nichž mají muži reprodukční přístup $\mathrm{k}$ více ženám, se počty potomků - tak jako ve světě zvířat - mohou odlišovat. Muž zde není limitován devítiměsíční předporodní a poté poporodní sterilitou jedné jediné manželky, může navíc oplodňovat ženy i ve svém relativně vysokém věku, nebot' si může dovolit mít za manželky i výrazně mladší ženy, než je on sám.

Odlišnost mezi muži nalézáme ovšem historicky i v monogamních společnostech. Může za to - stejně jako u zvířat - sociální status, který byl historicky pro mužskou plodnost rovněž navýsost důležitý. Mnohé kultury totiž vyvinuly normu primogenitury, která v rámci rodiny zajišt'ovala nejvyšší sociální status prvorozenému synovi - ten dědil rodinný majetek, a tím „zdědil“" také nejvyšší šanci na sňatek. Navíc na sňatek s takovou partnerkou, která byla ze stejné sociální vrstvy a u níž existovaly předpoklady, že je schopná přivést na svět řadu potomků (a tím udržet geny daného rodu v populaci). Na druhou stranu neprvorození synové končili jako bezdětní staří mládenci.

Samčí a samičí plodnost se liší také z hlediska „reprodukční motivace“. „Zatímco optimální [...] strategií samce je maximální intenzita, a tedy nevýběrovost v rozmnožování, samice musí upřednostňovat spíše kvalitativní hlediska. Svou pravděpodobnou reprodukční úspěšnost může ovlivnit především výběrem nejvhodnějšího pohlavního partnera, samce s co největší biologickou zdatností. Pro samici však není jednoduché určit, podle jakých kritérií si má partnera vybírat“" (Flegr 2007: 329-330). Nebyly v lidské populaci aranžované sňatky, při nichž rodiče $-\mathrm{s}$ důrazem na sociální status a majetek - pečlivě vybírali pro svého syna

7 To je odhad Bongaartse (1978). Novější údaje tuto dobu ještě zvyšují. Je to způsobeno odkládáním prvních (ale i dalších) porodů do vyššího věku (viz například Jensen a kol. 2001, Gnoth a kol. 2003).

8 Je to takový režim plodnosti, v němž muž a žena plodí děti bez ohledu na to, kolik jich už mají, a nesnaži se ukončit plození dětí před koncem plodného období ženy, nijak se nebrání početí a nepraktikují žádnou antikoncepci. 
vhodnou manželku či pro dceru vhodného manžela, s cílem podobnou (byt' neuvědomovanou) snahou položit dobré základy pro genetickou reprodukci a biologickou zdatnost? ${ }^{9}$

V lidské populaci se intenzita plodnosti muže a ženy odlišuje ještě v závislosti na věku. Paget a Timaeus (1994) stanovili na základě rozboru empirických dat pro mužskou a ženskou specifickou plodnost tzv. standardni model průběhu mužské a ženské plodnosti pro hypotetickou populaci, která nepraktikuje antikoncepci (viz obrázek 1). ${ }^{10} \mathrm{Z}$ obrázku je patrná mnohem delší reprodukční kariéra mužů ve srovnání s ženami; ženská křivka je strmější s vrcholem mezi 20-25 lety, mužská křivka je celkově plošší s vrcholem mezi 27-31 lety. Průměr mužského modelového rozložení je 38 let, modus 29 let a 98 \% mužské plodnosti je realizováno v rozmezí 20-65 let (tamtéž: 337).

Obrázek 1: Pagetưv a Timaeusưv model mužské a ženské plodnosti v závislosti na věku v hypotetické populaci nepraktikující antikoncepci

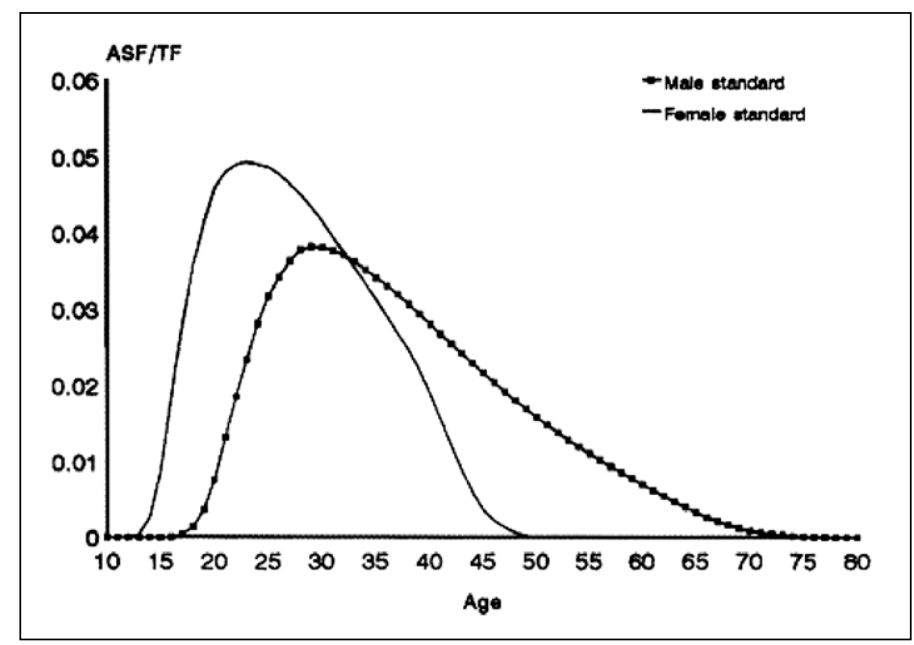

Zdroj: Paget a Timaeus (1994: 337).

Model je ovšem vždy určitou aproximací skutečnosti, takže je zřejmé, že relativní hodnoty specifických měr plodnosti podle věku a pohlaví vycházející z empirických dat mohou vykazovat poněkud jiné rozložení. Na obrázku 2 jsou vykresleny křivky specifických měr plodnosti podle věku mužů ve Francii, která zastupuje země s nízkou intenzitou plodnosti (data z roku 1980), v Pákistánu, země s vysokou intenzitou plodnosti (data z roku 1984) a Kamerunu, země s polygamními sňatečními normami (data z roku 1964). Průměrný věk

9 S drobným rozdílem, že monogamní kultury nepřipouštěly „strategii maximální intenzity samce“; polygamní ji však podporovaly.

10 Autoři přiznávají, že získat data o mužské plodnosti podle věku bylo obtížné. Vyšli proto z dat, která byla na základě speciálních terénních šetření publikována v Demografické ročence OSN. 
reprodukce byl pro Francii 30,6 roků, pro Pákistán 36,8 a pro Kamerun 46,6 roků. Úhrnná plodnost byla 2,0 dětí ve Francii, 8,6 v Pákistánu a 10,6 v Kamerunu (tamtéž: 338, tabulka 2).

Obrázek 2: Specifické míry plodnosti podle věku mužư ve Francii (1980), v Pákistánu (1984) a Kamerunu (1964)

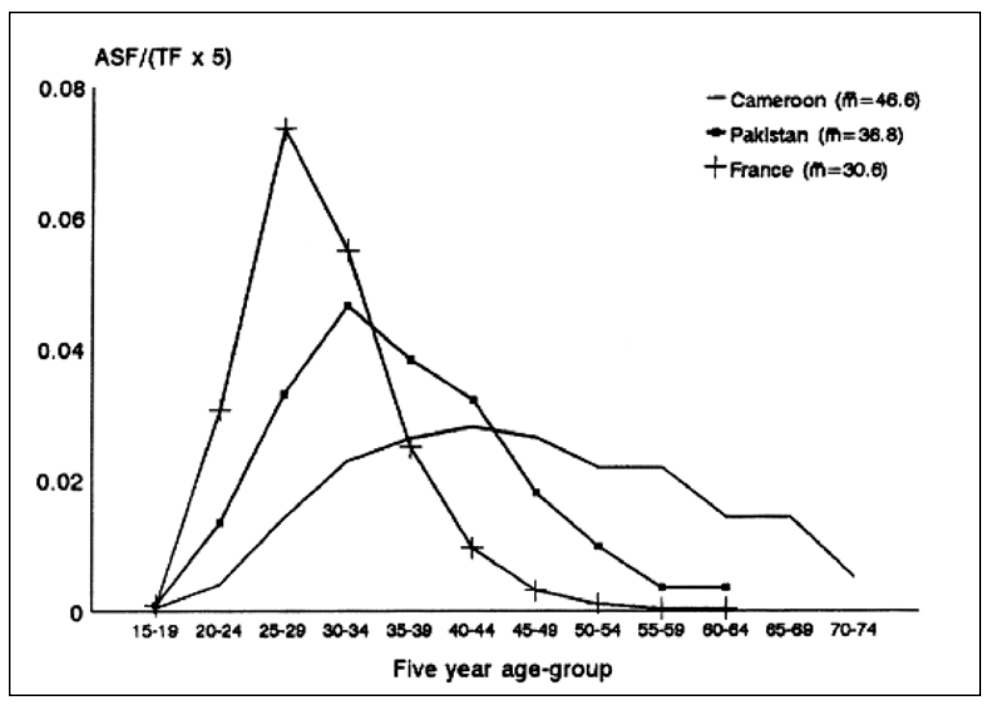

Zdroj: Paget a Timaeus (1994: 339).

Křivky rozložení specifických plodností zřetelně ilustrují rozdíl mezi monogamními a polygamními populacemi: kamerunská mužská plodnost (polygamie) je mnohem plošší, než monogamní plodnost francouzská a pákistánská, ale zato je rozprostřena do širokého věkového rozmezí. Je to tím, že mnohoženství umožňuje i starším kamerunským mužům, aby plodili děti se svými mladými manželkami. Ve francouzské křivce se zrcadlil evropský vzorec sňatečnosti, kdy muži a ženy jsou víceméně stejně staří (rozdíl činí asi dva roky), takže muži končí svou reprodukční dráhu přibližně ve stejném věku jako jejich ženy. V Pákistánu jsou často věkové rozdíly mezi manželi větší, takže děti plodí i muži starší 50 let, nebot' mají manželky, které jsou ještě v plodném věku.

Pro ilustraci rozdílů mezi mužskou a ženskou specifickou plodností si nyní ukažme u výše uvedených zemí distribuce specifických plodností žen. Jak je vidět na obrázku 3, který jsme sestavili z dat takového období, aby se co nejvíce blížilo údajům pro muže, je věkový vzorec plodnosti v Pákistánu a Kamerunu - navzdory rozdílnosti kultur - víceméně podobný a liší se pouze intenzitou úhrnné plodnosti (v obrázku 3 je údaj o úhrnné plodnosti v rámečku); francouzský se však od nich odlišuje ostrým vrcholem ve věkové skupině 25-29 let. Rozdíly ve vzorcích mezi mužskou a ženskou specifickou plodností jsou ovšem markantní. 
Obrázek 3: Specifické míry plodnosti podle věku žen ve Francii (1976), v Pákistánu (1985) a Kamerunu (1976)

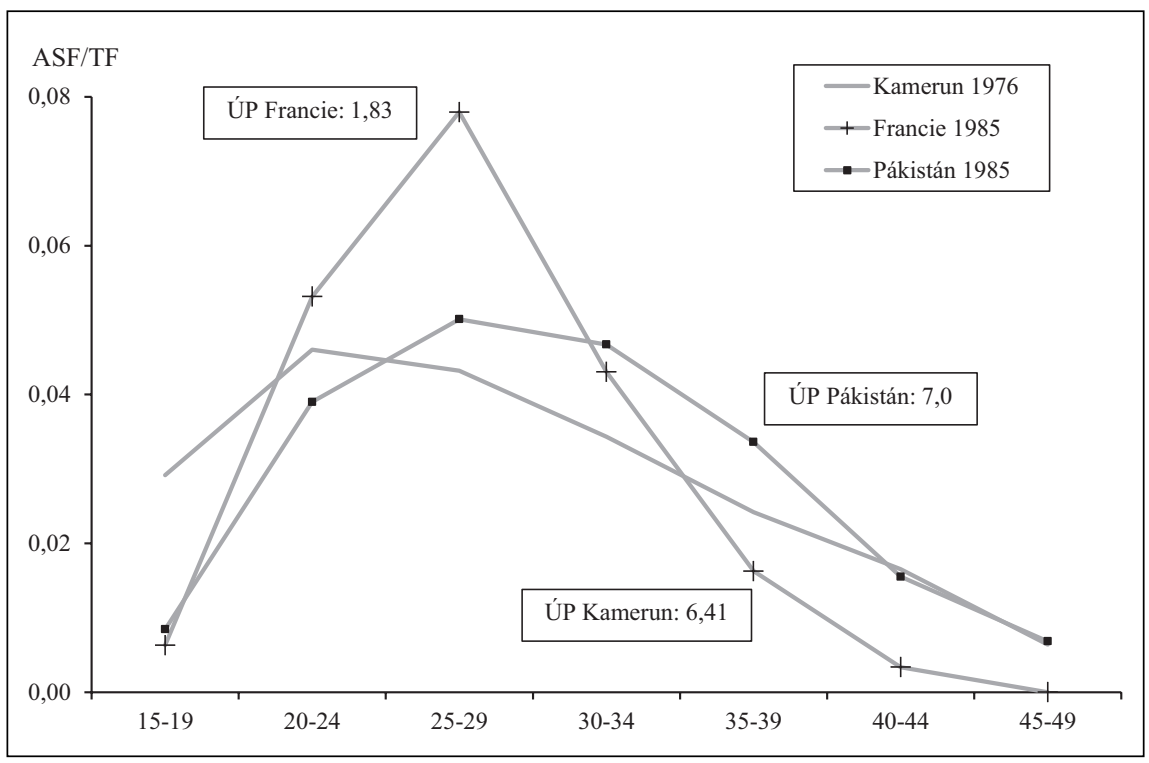

Zdroj: UN Data. Dostupné na www: <http://data.un.org>, databáze „Population“.

A abychom se nepohybovali pouze $\mathrm{v}$ datech zahraničních, konfrontujme modelový standard s reálnými empirickými daty českými. Z údajů ČSÚ, z hlášení o narození za rok 1993, jsme vypočítali specifickou plodnost mužů a žen. Výsledek je na obrázku 4. Zde jsou tvary rozložení podobné tvarům rozložení modelu Pageta a Timaeuse, avšak jasně ukazují na rozdíl mezi muži a ženami - úhrnná plodnost mužů byla nižší $(1,44)$ než úhrnná plodnost žen $(1,66)$. Důvody jsou dvojí a oba mají z hlediska tohoto ukazatele povahu především technickou. Jednak ve věku vysoké plodnosti převažují v naší populaci muži, ${ }^{11}$ takže při přepočtu na jednotku je jejich jmenovatel vyšší, což dává nižší výsledné číslo (svou roli také sehrává fakt, že muži mají navíc období plodnosti delší než ženy, tudíž počet potenciálních otců je v úhrnu vyšší než počet potenciálních matek, které mají období plodnosti kratší). Proto i ve striktně monogamních společnostech, v nichž by měl být počet dětí u mužů a žen stejný, je z hlediska statistického ukazatele úhrnná plodnost mužů nižší než úhrnná plodnost žen. Druhým důvodem je skutečnost, že česká mužská data jsou zkreslena neúplnými údaji o mimomanželských porodech, u nichž žena neuvedla otce (detailněji viz níže).

11 Což je způsobeno vyšším počtem rodících se chlapečků ve srovnání s děvčátky. Počty mužů a žen se na počátku 90. let vyrovnávaly mezi 44.-45. rokem života. 


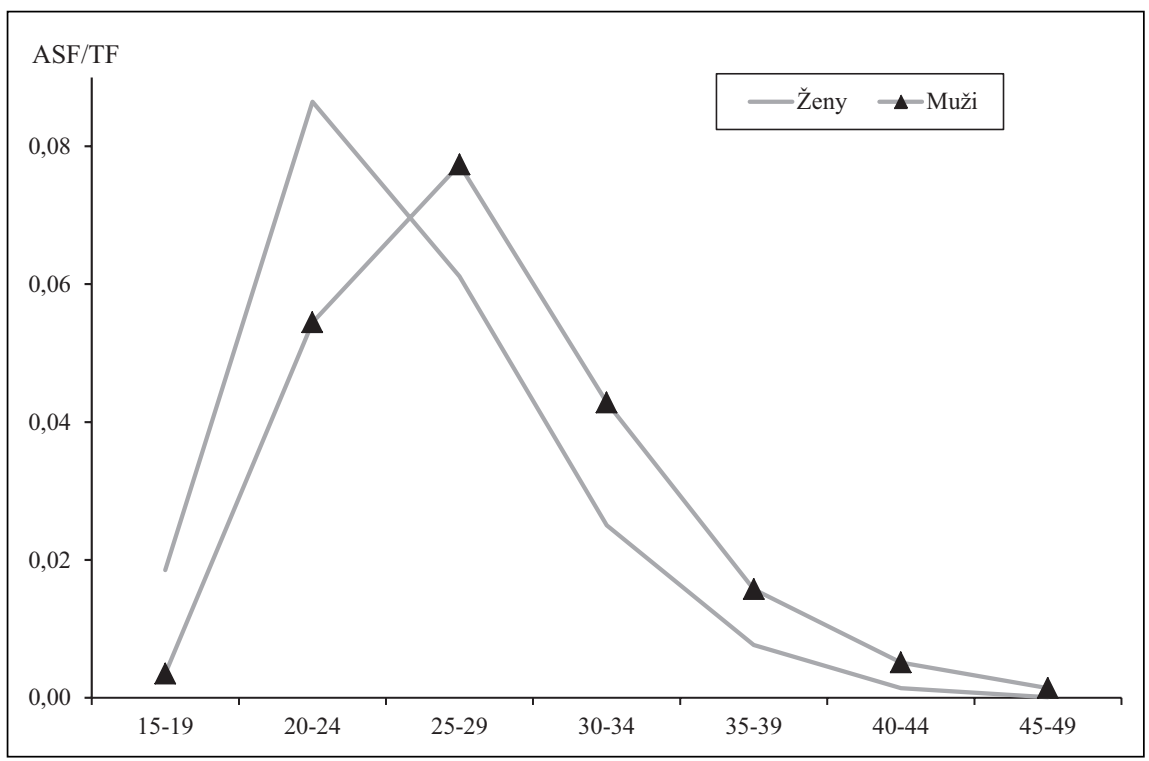

Zdroj: Čsú, Hlášení o narození, 1993.

Podobnost rozložení měr specifických plodností podle věku u mužů a žen by se však měla začít $\mathrm{v}$ současných vyspělých společnostech ztrácet a křivky by se měly ještě více odlišovat. V pozadí tohoto trendu stojí dvě skutečnosti: 1) V posledních desetiletích se v evropských zemích monogamní sňatkový vzorec proměnil v tzv. sériovou monogamii - legalizace rozvodů a jejich rozšíření vedlo k opakovaně uzavíraným sňatkům, přičemž častěji se opakovaně žení muži, kteří si v novém svazku (byt' ve vyšším věku) pořizují děti, zatímco ženy zůstávají po rozvodu často samy - jde de facto o moderní formu polygynie. 2) Stále vyšší podíl dětí se rodí svobodným ženám a i zde je určitá pravděpodobnost, že otcem bude ženatý nebo rozvedený muž, který již děti má.

\section{Chybějící muži ve výkladových schématech faktorů fertility}

Je dobře známo, že reprodukční chování prochází ve vyspělých společnostech od 60 . let minulého století postupnou proměnou, pro kterou se vžil název druhý demografický přechod (van de Kaa 1987). V jejím rámci se objevují nejrůznější výklady příčin demografických změn a z hlediska našeho tématu je podstatné, že jejich častým rysem je vyzvedávání ženy jakožto aktérky, která je nositelkou nového reprodukčního chování. Udělejme si nyní stručný přehled několika konceptualizací.

Základním rysem moderního reprodukčního chování, jak se shodují mnozí autoři, je individuální (a racionální) volba. Jelikož reprodukci zajišt'uje svazek muže a ženy, je pro její pochopení potřeba brát v úvahu nejen individuální volby, ale také volby, které vznikají 
na základě interakce manželů. Důraz na individualitu jedince proměnil pochopitelně i pohled na manželství a rodinu. $\mathrm{V}$ době před demografickým přechodem bylo manželství výrazným bodem životní dráhy každého individua. Znamenalo nezávislost na rodičích, dodávalo status dospělosti, bylo spojeno s pravidelným sexuálním životem a s rodičovstvím. Smyslem manželství byla prokreace a děti byly v ohnisku pozornosti rodiny. Pro zdárné fungování manželství byly předepsány komplementární - a tedy odlišné - mužské a ženské role: „muži obstarávali finanční zdroje a poskytovali společnost, ženy byly odpovědné za udržování či zvyšování kvality života všech členů domácnosti“ (Lesthaeghe 1995: 19). V průběhu přechodu toto mizí a cílem manželství je egalitární partnerský vztah, v němž štěstí jedince, muže a ženy, je raison d'être jeho existence.

Směřování $\mathrm{k}$ racionálním reprodukčním volbám, které by byly $\mathrm{v}$ souladu $\mathrm{s}$ důrazem na individuální štěstí, bylo silně podpořeno technologickou inovací, jíž byla spolehlivá ženská hormonální antikoncepce. Její široká př́ítomnost v moderní sexualitě bývá někdy označována jako „druhá antikoncepční revoluce“12 a van de Kaa (1997) chápe tuto inovaci jako klíčový faktor v celém řetězci událostí, které vytvářejí druhý demografický přechod. Nová antikoncepční technologie spolu s legalizací sterilizace a potratů totiž nejenže definitivně oddělily sex od početí, ale měly také jeden důležitý dopad na vědomí nových kohort. Pomohly odstranit strach $\mathrm{z}$ nežádoucího těhotenství a přispěly $\mathrm{k}$ tomu, že se naplno mohla uplatnit spontaneita a radost ze sexu, ale - a to především - ženy získaly naprostou autonomii v otázkách reprodukce. Mohly ji začít řídit zcela podle vlastních přání a představ.

Jako součást celého procesu hlubokých proměn $\mathrm{v}$ demografickém chování je dále vyzvedáván prvek ideologický, který se stále častěji objevuje ve veřejném diskursu, totiž důraz na autonomii žen. Ženy v každodenním životě stále více trvají na svém právu rozhodovat o svém vlastním životě a být nezávislé na mužích. Idea sebeuvědomění a seberealizace žen stejně jako idea genderového egalitarismu dostala ještě silnější význam v okamžiku, kdy ženy zaplnily střední školy a univerzity a vstoupily masově do světa práce. Nová vzdělanostní úroveň žen otevřela této sociální kategorii zcela nové vyhlídky, především však pocit uspokojení z práce mimo domov, z úspěchu v zaměstnání, z výdělku a z celkové nezávislosti.

Výklady o proměně reprodukčního chování svého času značně ovlivnil i ekonom Becker (1981), jenž použil ve svém výkladovém schématu teorii ekonomické směny (exchange theory). Sňatek konceptualizoval jako obchod - muži se žení a ženy se vdávají proto, nebot' sňatek (obchod) jim přináší větší zisky, než kdyby zůstali svobodnými (to je neobchodovali). $Z$ důvodů, aby manželstvím maximalizovali zisk, se na sňatkovém trhu vyhledávají partneři s komplementárními vlastnostmi a dovednostmi. V sedmdesátých letech však nastala v tomto mechanismu změna. Becker ji vysvětluje tak, že v situaci, kdy ženy zvyšují svou participaci na trhu práce, a tím také zvyšují své výdělky a ekonomickou nezávislost, jsou celkové zisky z manželství snižovány, takže vyhledávání partnera (obchod) je váhavější a trvá celkově déle.

12 Koncept dvou antikoncepčních revolucí vnesli do demografického uvažování Ryder a Westoff (1977). Ta první byla založena na neefektivních metodách regulace počtu dětí v rodině (a na silné motivaci rodičů omezovat svou plodnost) - $\mathrm{v}$ konečném důsledku vedla $\mathrm{k}$ prvnímu demografickému přechodu. Ta druhá spočívala v zavedení moderních účinných a spolehlivých antikoncepčních prostředků na počátku šedesátých let. 
Becker tak spatřuje ve vysoce specializovaných manželských a rodinných rolích ústřední motiv sňatečního a rodinného chování a považuje vzrůstající zaměstnanost žen a jejich rostoucí ekonomickou nezávislost za hlavní faktory, jež negativně ovlivňují existenci a fungování rodiny (a míru její reprodukce) v soudobé společnosti. Vedou totiž k odkládání sňatků a ke zvyšující se manželské nestabilitě. K tomu se přidává svým názorem i Westoff (1983), který ř́ká, že v situaci, kdy v důsledku ekonomické nezávislosti již přestalo platit, že ženy nabízejí v manželství plození dětí a domácí služby výměnou za svou ochranu a ekonomický status, jenž se odvíjí od statusu jejich manželů, ztrácí sňatek své racionále.

Teorii směny pro vysvětlení proměny manželského chování využila také Oppenheimerová (1988). Ta ale tvrdí, že svou roli hrají ne podmínky na trhu práce, ale na trhu sňatkovém. Vyšší vzdělání žen, vyšší míra jejich zaměstnanosti a narůstající finanční nezávislost zvýšily požadavky žen na kvalitu partnera a změnily představy o tom, jaký partner/manžel je pro ženu ještě minimálně akceptovatelný. Podle Oppenheimerové je proto možné chápat prodlužující se dobu chození spolu a nesezdané soužití, které oddaluje uzavření sňatku, jako výraz pečlivého hledání vhodného partnera.

Někteří autoři jdou v těchto úvahách ještě dále a tvrdí, že dnešní celkově vzdělanějši ženy vlastně nepotřebují hledat na sňatkovém trhu partnera, který by jim pomohl k sociálnímu, majetkovému a statusovému vzestupu - jsou totiž sociálně vysoko i bez něj. Takže ženy z tohoto hlediska manželství vlastně nepotřebují. Takový posun v životní orientaci žen je mnohým autory (viz např́klad Westoff 1983, Lesthaeghe 1995, Hoffmann-Nowotny 1987, Keyfitz 1986) považován za jeden z nejvýznamnějších pro pochopení celkových proměn rodinných struktur. V podobném rámci se pohybuje i Badinterová (1998), když na základě historické analýzy tvrdí, že jakmile má žena společenské, intelektuální nebo profesionální ambice a má i prostředky na jejich naplnění, láká ji mnohem méně investovat svůj čas a energii do výchovy dětí. Jak vidět, objevuje se muž v těchto vysvětleních jen sporadicky. A jsou to také ženy, o nichž jsou zaznamenávány rutinní statistiky indikující některé charakteristiky reprodukčního chování, a jsou to rovněž ženy, které jsou jednotkami speciálních výzkumných šetření na téma proměn plodnosti.

Vynecháváním mužů z analýzy přicházíme o nesmírně užitečné informace. Je navíc s podivem, že ačkoliv se genderová perspektiva stala důležitou optikou, jejímž prostřednictvím jsou nahlíženy nejrůznější aspekty života moderních společností, je v tak zásadní věci, jako je biologická reprodukce, absentující. V jedné z několika málo knih, která pojednává o mužské plodnosti, podává Zhangová (Zhang 2011) podstatný důvod, proč jsou výzkumy fertility centrovány na ženy. Demografii a sociologii chybějí teorie fertility, které by byly založeny na chování mužů. Což jsme na několika ukázkách výše předvedli.

\section{Objevující se muži v reprodukci}

$\mathrm{V}$ poslední době se situace ve výzkumu reprodukce začala měnit a mužský prvek začal být součástí výzkumné agendy. Je ale pravda, že většina studií, které v souvislosti s plodností a reprodukcí studují také muže, se provádí v méně rozvinutých zemích - především v Africe -, a že se soustřed'ují na plánování rodiny a aplikaci antikoncepce. V zemích vyspělých se muži dostávají do centra výzkumné pozornosti zatím jen zvolna, byt' se již objevili autoři 
a autorky, kteří data o mužích ve svých výzkumech sbírají (viz například Goldschneider a Kaufman 1996; Sonenstein a kol. 1997; Rendall, Clarke, Peters, Nalini, a Verropoulou 1999; Green a Biddlecom 2000; Bledsoe, Lerner a Guyer 2000; Toulemon 2001; Tölke a Diewald 2003; Alich 2007; Rotkirch a Basten 2010; Zhang 2011). Jejich důraz na muže vychází z úvahy, že pro výsledný počet dětí u každého páru (pro jeho konečnou plodnost) jsou velmi důležité vzájemné každodenní interakce mezi mužem a ženou, které pochopitelně zahrnují i vyjednávání o počtu dětí. Jaké jsou postoje mužů a žen v tomto vyjednávání, jak se mění jejich intence a v jakém mocenském poli se dělají rozhodnutí o počtu dětí, je zatím nejasné, je však zrrejmé, že tyto informace mohou pomoci lépe porozumět procesům, které vedou u párů $\mathrm{k}$ výslednému počtu dětí.

Například Goldscheider a Kaufman (1996) tvrdí, že tím nejdůležitějším indikátorem, který nám v demografických a sociologických studiích chybí, je úroveň vzájemné oddanosti (commitment) mezi mužem a ženou. Současně požadují, aby tyto výzkumy zahrnovaly také mužské vnímání sňatků a rodičovství, jakožto důležitého aspektu problému.

V roce 2000 se objevila první kniha (Bledsoe, Lerner a Guyer 2000), která se cele zabývá problematikou mužské fertility a vznikla na základě speciálního semináře IUSSP (International Union for the Scientific Study of Population) v roce 1995. Jednotlivé kapitoly ukazují, že zabývat se mužskou plodností může vést k lepšímu porozumění jednotlivým dimenzím reprodukčního chování a rodičovství.

Zajímavé výsledky přináší Toulemon (2001). Srovnal mužskou a ženskou plodnost a velikost rodiny na základě výzkumu rodinných historií ve Francii v roce 1999. Zjistil, že mužská plodnost je o $6 \%$ nižší než ženská, a za rozhodující faktor tohoto výsledku pokládá skutečnost, že muži ve výzkumech neuvádějí všechny děti, které zplodili. Odlišný je podle Toulemona také celkový počet dětí v rodině. Zatímco muži zůstávají častěji bezdětní než ženy, mají na druhé straně častěji než ženy velké rodiny.

Tölke and Diewald (2003) zkoumali dopad povahy práce a různých profesionálních kariér na přechod k otcovství v Německu. Tvrdí, že propojení mezi prací a plodností se řídí odlišnými pravidly pro muže a pro ženy a že v důsledku konzervativní povahy sociálního státu je zde hluboce zakořeněn model muže jakožto živitele rodiny, který hraje rozhodující roli v chování mužů při zakládání rodiny. Autoři také uvádějí, že v Německu mají na mužskou plodnost stále vliv sociální status a složení rodiny původu.

Analýza ruských údajů z výzkumu Generation and Gender Survey ukázala, jak nás informuje Alich (2007), že při srovnání věku v době porodů, časování porodů a počtu dětí se ukazuje, že muži a ženy mají relativně společné reprodukční vzorce. Nicméně nabádá, aby se ve výzkumu mužské plodnosti a jejích vzorců v Rusku dále pokračovalo a to v mnohem detailnějším záběru.

Mnohé studie se soustřed'ují na motivace k rodičovství, bohužel analytickou jednotkou těchto výzkumů bývá žena, o motivech mužů se pojednává jen zř́ídka. Výzkumné výsledky ovšem naznačují, že ženy a muži nemusejí mít nutně stejné postoje, preference a cíle, co se týče počtu dětí (např́ílad Becker 1996, 1999; Thomson 1997; Thomson a Hoem 1998; DaVanzo a kol. 2003; Berrington 2004). Zajímavé téma vnesli do mužských fertilitních studií finští badatelé Rotkirch a Basten (2010), nebot' se zabývali otázkou, zdali i muži mají to, čemu se u žen říká „,biologické hodiny“ a „touha po dítěti“. Na základě speciálního 
výběrového šetření zjistili, že touhu po dítěti vyjadřovali jak ženy, tak muži - obě pohlaví pocit’ovala silnou touhu po dítěti několikrát $\mathrm{v}$ životě. Nicméně intenzita byla odlišná: touhu po dítěti nikdy nepocítilo více mužů než žen a častou touhu po dítěti vyjádřil vyšší podíl žen než mužů. Mužská touha po dítěti se projevovala především v souvislosti s rozhodnutím o početí prvního dítěte.

V roce 2003 publikoval velmi zajímavý článek, v němž představil svou teorii konfliktních preferencí, Voas. Vyšel z toho, co dnes zdůrazňuje mnoho autorů, že preference jsou pro reprodukční proces velmi důležitým prvkem, nebot' jestliže dnes lidé úspěšně kontrolují početí, a tím pádem jsou schopni je plánovat, je faktor volby (preference), tedy to, co lidé osobně v životě chtějí, jedním z nejdůležitějších. Voas (2003) navíc zdůraznil, že podstatné pro počet potomků není chování ženy, nýbrž (odlišné) partnerské preference. Jestliže připustíme, že partneři mají možnost volby mezí tím, zda mít, či nemít děti, pak nesmíme předpokládat, že jejich konečný počet závisí čistě na ženě samotné, říká Voas. Pro počet dětí $\mathrm{v}$ rodině je podle Voase klíčové, jaké jsou individuální preference manželů/partnerů a jakým způsobem spolu tyto preference interagují.

V českém prostředí, pokud je nám známo, nikdo o mužské plodnosti cíleně zatím nebádal a žádný speciální výzkum na toto téma neproběhl. Jeden z mála výzkumů, v němž byla mužská plodnost analyzována, byl v České republice proveden v roce 2005 . Z něj vzniklo několik statí, které se zabývaly reprodukčními intencemi mužů a žen (viz Chromková Manea a Fučík 2007, Fučík a Chromková Manea 2008, Chromková Manea a Fučík 2011 [v tisku]). Výsledky zatím naznačují, že rozdíly v reprodukčních intencích mužů a žen jsou na úrovni páru jenom malé.

Se zahrnutím mužů do statistik indikujících reprodukční chování a do výzkumů reprodukčního chování, přiznejme, to ale není tak úplně jednoduché. Některé důvody, proč muži v demografických analýzách plodnosti chybějí, uvádějí již zmíněné Greenová a Biddlecomová (2000) a také Zhangová (2011). Podle nich za to částečně může dnes již klasický (anglosaský) text o demografických metodách analýzy Shryocka a Siegela (1976). Ti totiž zdůvodnili, proč nejsou počítány demografické ukazatele pro mužskou plodnost, takto: a) mužské reprodukční období se nedá tak přesně věkově ohraničit, jak období ženské; b) s ženami se lépe dělají výzkumné rozhovory, nebot' jsou častěji doma než muži; c) pokud děti nežijí s oběma rodiči, je velmi pravděpodobné, že budou žít spíše s matkou než s otcem. A jelikož demografie je převážně počítáním, rríkají Greenová s Biddlecomovou, je z jejího hlediska jednodušší a postačující sbírat informace o plození dětí pouze od jednoho pohlaví. Matky si navíc lépe než otcové pamatují, kdy měly potrat, zdali jim po narození jejich malé dítě zemřelo a konec konců, jelikož o mateřství neexistují žádné pochyby, vědí ženy přesně, kolik dětí porodily. Muži, na rozdíl od žen, si ne tak dobře pamatují, kolik dětí (a s kým) vlastně zplodili. Není to vždy jejich vina, nebot' občas se o těhotenství partnerky, zvláště byla-li to náhodná známost, nemusí ani dozvědět. Nebo naopak, muž si může myslet, že on je otcem dítěte, které porodila jeho manželka, avšak skutečným otcem je někdo jiný. Muži mají navíc tendenci v odpovědích na výzkumné otázky počet svých dětí snižovat.

O míře zkreslení v uváděných počtech dětí se pokusili vypovědět Rendall a kol. (1999). Na základě analýzy dat z U. S. Panel Study of Income Dynamics a z British Household Panel Survey zjistili, že zkreslení ve „sdělování údajů o dětech“ se týká třetiny až poloviny dětí, 
častěji nastávalo u dětí nemanželských, méně často pak u dětí z předchozího (předchozích) manželství.

Další důvod, proč se demografie v kontextu fertility vyhýbá mužům, je analytický. Spojovat informace od manžela a manželky do jednoho explanačního modelu je obtížné, nebot' u mnoha proměnných vyvstává při analýze problém kolinearity - jelikož manželé tíhnou k sociální homogamii, vykazují mnoho charakteristik podobných nebo stejných. A kolinearita je strašákem každého regresního modelu.

Český statistický úřad získává údaje o narození ze standardního formuláře ČSÚ, jímž je hlášení o narození. Data jsou získávána z formulářů, které se vyplňují s matkami nově narozených dětí v porodnici, součástí údaje je i informace o pořadí narození a o vzdělání matky a samozřejmě i o jejím věku. Jsou zde i údaje o otci (mimo jiné o jeho věku a vzdělání), ty však nejsou u všech narozených dětí úplné. Podle zákona je totiž otcem dítěte u vdaných žen automaticky určen manžel, ${ }^{13}$ svobodné nebo déle rozvedené matky nemusí u porodu otce jméno uvádět. Pokud je matka čerstvě rozvedená nebo její manželství zaniklo úmrtím manžela a dítě se narodí do 300 dní od zániku manželství, je do rodného listu zapsán její bývalý manžel. V roce 2010 nebyly uvedeny údaje o otci u 10,2 tisíců živě narozených dětí, což je asi $9 \%$ z celkového počtu všech narozených dětí, a tento podíl byl zaznamenán i v letech 2007-2009 (Vývoj 2011: 21). Zde je právě zdroj jistého zkreslení pro výpočty ukazatelů plodnosti, o němž jsme se zmínili v souvislosti s grafem 4.

\section{Chybějící muži v českých ukazatelích reprodukčního procesu - inventura}

Reprodukce jakožto plození dětí a její výsledek jakožto výsledný počet dětí v rodině je složitým procesem, který je ovlivněn mnoha faktory, z nichž my nyní uvedeme jen ty, které považujeme v kontextu interakce muže a ženy za nejdůležitější. Jelikož k početí dítěte je zapotřebí oplodňujícího sexuálního aktu mezi mužem a ženou, musí se především a nejdříve nalézt vhodní partneři. Označme tento faktor jako nalezení partnera. Na základě intenzivních emocí, jimž se říká láska, a na základě vzájemného sexuálního zalíbení spolu partneři zakládají sexuální jednotku (faktor sexuálního soužiti), které ř́íkáme domácnost. Zakládají ji ponejvíce aktem sňatku, v současnosti však také pouhým sestěhováním se a žitím spolu nesezdaně (to je bez oddacího listu) - tedy faktor sňatku/soužití. Láska a sex jim umožní naplnit potřebu mít dítě (není to však pravidlem, někteří se k reprodukci neodhodlají nikdy), a pokud láskyplná a sexuální záliba jednoho ve druhém přetrvává a pokud tomu celkové zkušenosti s existencí prvního dítěte nebrání, rozhodnou se možná pro další dítě, případně další děti ( $f a k$ tor reprodukčnich preferenci). Ne všechny svazky ovšem vydrží, takže se mnohé rozpadají (v případě nesezdaných soužití) nebo se rozvádějí (v případě manželství) - faktor rozvodu/ rozchodu. Po rozvodu/rozchodu se jedinci snaží (většinou) nalézt nového partnera/partnerku, aby s ní/m založili novou domácnost (popřípadě aby žili ve formě svazku LAT - v odděleném soužití) - faktor opakovaných š̆atků/svazků - a zopakovali některé z výše vyjmenovaných

13 Není to však vždy skutečností. Odhaduje se, že asi 4-10 \% dětí může mít jiného genetického otce než je ten, který je uveden v matrice. 
prvků procesu reprodukce - faktor dalši reprodukce (nebo také faktor sériově-monogamni reprodukce).

Jak je z výčtu těchto faktorů zřejmé, je proces reprodukce celkově založen na intenzivní interakci muže a ženy. Abychom tomuto procesu rozuměli, je také zřejmé, že potřebujeme znát informace o průběhu těchto interakcí, o tom, jak probíhají rozhodovací akty, jaké se za nimi skrývají motivy a v jakém sociálním kontextu se celá reprodukce odehrává. Uděláme-li si inventuru toho, jaké informace máme o výše uvedených faktorech reprodukce $\mathrm{k}$ dispozici, budeme muset smutně konstatovat, že jich není př́liš mnoho, a jelikož navíc diskriminují muže, jsou nutně neúplné. Vezměme to ale pěkně popořádku.

\section{Faktor sexuálního soužití}

O sexuálních aktivitách české mladé i dospělé populace jsme díky opakovaně prováděnému psychologickému a sexuologickému výzkumu Weisse a Zvěřiny informováni celkem pravidelně a poměrně bohatě. $Z$ jejich reprezentativních výzkumů na vzorku české populace 1000 mužů a 1000 žen ve věku nad 15 let, které probíhají v pětiletých intervalech od roku 1993 (1998, 2003 a 2008), máme časové řady o věku koitálního debutu, o počtu sexuálních partnerů, o frekvenci sexuálního styku, o formách používané antikoncepce, o sexuálních poruchách a o postojích $\mathrm{k}$ sexuálním otázkám (k základním sdělením viz např́íklad Weiss a Zvěřina 2009). Všechny jejich publikované informace jsou důsledně tříděny podle pohlaví, což je dáno implicitním sexuologickým předpokladem o odlišné sexualitě muže a ženy. Jsou to všechno důležitá data, ale k pochopení reprodukčního procesu nám pomáhají jen v omezené míře, což samozřejmě není vina tohoto výzkumu. Podstatnou informací ale pro nás může být údaj o počtu sexuálních partnerů: muži ve sledovaném období 1993-2009 uváděli v průměru 9-10 sexuálních partnerek, ženy uváděly v průměru pět sexuálních partnerů. $Z$ této častější (deklarované) mužské promiskuity se může odvíjet i potenciálně vyšší mužská plodnost (v některých prŕípadech však i neuvědomělá). Také údaj o aplikaci antikoncepčních metod je pro proces reprodukce důležitý. V roce 2008 používaly velmi spolehlivé metody antikoncepce (hormonální, tělísko nebo kondom) menší podíly mužů než žen: $69 \%$ : $78 \%$. Z tohoto údaje můžeme dedukovat, že muži jsou z hlediska chráněného styku méně starostliví než ženy, takže opět jejich konečná plodnost by mohla být potenciálně vyšší než ženská.

\section{Faktor sňatku/soužití}

O zakládání sňatků a o jevech souvisejících (o sňatečnosti) informuje pravidelně demografická statistika. Z těchto údajů víme, že celkově se počet uzavíraných sňatků v České republice od roku 1992 s mírnými oscilacemi pravidelně snižuje. ${ }^{14}$ Mnohé atributy sňatečnosti jsou získávány pro obě pohlaví. Proto například víme, že ze všech uzavíraných sňatků tvoří sňatky prvního pořadí v posledních letech 73-75 \% u mužů i žen (Vývoj 2011: 11). O intenzitě prvních sňatků vypovídá ukazatel prvosňatečnosti, který udává, jaký podíl mužů

14 V roce 1992 bylo uzavřeno asi 74 tisíc sňatků, v roce 2010 to bylo již jen 47 tisíc. 
(respektive žen) by do svých padesáti let uzavřel první sňatek za předpokladu zachování intenzit sňatečnosti svobodných daného roku. Ochota vstupovat do sňatku je mnohem nižší u mužů než u žen, trend je však u obou pohlaví od roku 1991 výrazně klesající, ${ }^{15}$ což jasně dokládá, že uzavírání sňatku je pro mladé české muže (ale i ženy) stále méně atraktivní. $\mathrm{K}$ jakým interakcím mezi mužem a ženou při rozhodování, zdali sňatek uzavř́ít nebo ne, dochází a které z pohlaví je sveřepější při odmítání uzavřít sňatek, z údajů demografické statistiky nezjistíme. Na to by bylo potřeba provádět speciální sociologicko-demografický terénní výzkum. O uzavírání nesezdaných soužití toho víme jen málo (některé informace lze nalézt ve Vítečková 2010). Zdrojem určité informace o podílu nesezdaně kohabitujích párů může být sčítání lidu, kdy lze nesezdané soužití rekonstruovat s určitou mírou nepřesnosti na základě údajů o místě bydliště a o rodinném stavu. ${ }^{16}$ Analytické údaje, které existují o př́ípadě sňatečnosti, však bez speciálního výzkumného šetření o nesezdaném soužití nezískáme.

\section{Faktor reprodukčních preferencí}

Také údaje o plodnosti shromažd’uje pravidelně česká demografická statistika a získává je z hlášení o narození. Z ní známe vývoj ukazatele úhrnné plodnosti, nevíme ale, jaká je úhrnná plodnost mužů, nebot' tu česká statistika neuvádí. Dále víme, že při nízkém počtu porodů se od roku 1990 permanentně zvyšoval podíl dětí narozených svobodným matkám (z $9 \%$ v roce 1990 na $40 \%$ v roce 2010). Nevíme ale, jaký byl rodinný stav otců těchto dětí, a ani nevíme, zdali matka nebyla svobodná pouze de iure, avšak de facto žila v domácnosti s nějakým partnerem. Víme, že nemanželské děti se rodí velmi často mladým matkám (ve věkové skupině do 20 let bylo z narozených dětí $92 \%$ nemanželských a ve věkové skupině 20-29 let bylo 45 \% dětí nemanželských). Nelze však přesně určit, jak byli v průměru staří otcové těchto dětí, nebot' údaje o otci chybějí. Dále víme, že nemanželsky se děti rodí velmi často ženám, které dosáhly pouze základního vzdělání (ze všech dětí narozených těmto matkám jich bylo $75 \%$ nemanželských a v podsouboru žen s výučním listem se nemanželsky narodilo $50 \%$ dětí). ${ }^{17} \mathrm{Nic}$ však nevíme o vzdělanostní struktuře otců.

Proměnily se také vzorce plodnosti podle věku, kdy se porody přesouvají z mladších věkových skupin do těch starších (nicméně po 45. roce věku u nás již ženy de facto nerodí) - informace zde však máme pouze o ženách, muži v těchto rozborech chybějí. Podstatně se také zvýšil věk v době prvního sňatku žen (z 22,5 roku v roce 1990 na 27,6 roků v roce 2010). Nejsme však schopni vypočítat průměrný věk otce v době, kdy mu manželka porodila první dítě, což je způsobeno již výše zmíněnými chybějícími údaji o otcích - mimochodem v datech z hlášení o narození z let 1993-2004 chybí záznamy o otcích ve 20 \% prípadů.

15 Zatímco v roce 1991 by do 50 let uzavřelo sňatek $84 \%$ mužů a $91 \%$ žen, v roce 2010 to bylo již jen 55 \% mužů a 62 \% žen (Vývoj 2011: 13). Průměrný věk v době prvního sňatku byl v roce 2010 u mužů 31,0 let, u žen 28,2 roků (ČSÚ, <www.czso.cz/csu>, data z roku 2011 ).

16 O vývoji v intercensálním období (v letech mezi sčitáními) se však nedozvíme nic.

17 Všechny údaje v tomto odstavci jsou převzaty z publikace ČSÚ - Vývoj obyvatelstva České republiky $v$ roce 2010 (2011). 
Statistika také sleduje míry plodnosti podle rodinného stavu, avšak opět pouze u žen, muži v těchto údajích chybějí.

\section{Faktor rozvodu/rozchodu}

Rozvodovost je pravidelnou každoroční kapitolou ve statistických údajích o českém demografickém vývoji. Proto víme, že česká manželství se poměrně houfně rozvádějí. Průměrná délka manželství při rozvodu byla v roce 2010 12,7 roku (Vývoj 2011: 6), a jelikož úhrnná rozvodovost byla v tom roce $50 \%$, pak to znamená, že každé druhé manželství skončí v Česku rozvodem, a to v průměru po 12,7 letech jeho trvání. Pokud se rozvedení odhodlají k novému sňatku, pak tak činí muži i ženy v průměru po 7-8 letech. A další sňatek o něco častěji uzavírají muži než ženy. ${ }^{18}$

\section{Závěr}

V tomto článku jsme se pokusili představit tematiku mužské reprodukce a sdělit důvody, proč se domníváme, že je potřeba se jí v současnosti zabývat stejně detailně a intenzivně, jako je tomu u reprodukce ženské. Jsme spolu s narůstajícím počtem zahraničních badatelů přesvědčeni, že údaje o mužské reprodukci a jejích kontextech nám pomohou lépe pochopit (a tudíž i vysvětlit), proč se v postmoderních společnostech setkáváme s nízkou úrovní plodnosti.

Na tento článek navážeme dalším, který bude založen na analýze existujících a dostupných dat o mužské reprodukci v České republice. Poté uvedeme další články založené na speciálním sociologickém šetření mužského reprodukčního chování, které proběhlo v ČR na konci roku 2011. Tím, věříme, položíme základ mužským reprodukčním studiím.

\section{Literatura}

ALICH, David. Differences Between Male and Female Fertility in Russia - An Evaluation of Basic Pattern and Data Quality Using the First Wave of the Russian GGS [online]. MPIDR Working Paper. 2007, [cit. 2011-03-29]. Dostupné na www: <http://demogr.mpg.de/papers/working/ wp-2007-015.pdf $>$

BADINTER, Elisabeth. Materská láska od 17. storočia po súčasnost'. Bratislava: Aspekt, 1998. 277 s. ISBN 80-85549-04-2.

BARRETT, Louis.; DUNBAR, Robin; LYCETT, John. Evolučni psychologie člověka. Praha: Portál, 2007. 512 s. ISBN 80-7178-969-0.

BECKER, Gary. A Treatise on the Family. Cambridge, Mass.: Harvard University Press, 1981. 288 s. ISBN 0674906977.

BECKER, Stan. Couples and Reproductive Health: A Review of Couple Studies. Studies in Family Planning. 1996, roč. 27, č. 6, s. 291-306. ISSN: 00393665.

18 Úhrnná sňatečnost rozvedených se snížila o dva procentní body na 38,4 \% u mužů, přičemž u nich poprvé od roku 2002 (apod.) poklesla pod hladinu 40 procent, a na 37,2 \% u žen (Vývoj 2011: 14). 
BECKER, Stan. Measuring Unmet Need: Wives, Husbands or Couples? International Family Planning Perspectives. 1999, roč. 25, č. 4, s. 172-180. ISSN: 01903187.

BERRINGTON, Ann. Perpetual Postponers? Women's, Men's and Couples' Fertility Intentions and Subsequent Fertility Behaviour [online]. S3RI Applications Working Paper A04/09. 2004, [cit. 20011-05-09]. Dostupné na www: <http://eprints.soton.ac.uk/7805/>

BLEDSOE, Caroline; LERNER, Susana; GUYER, Jane I. Fertility and the Male Life-Cycle in the Era of Fertility Decline. New York: Oxford University Press, 2000. 376 s. ISBN 0-19-829444-1.

BONGAARTS, John. A Framework for Analyzing the Proximate Determinants of Fertility. Population and Development Review. 1978, roč. 4, č. 3, s. 105-132. ISSN: 0098-7921.

DaVANZO, Julie a kol. How Well do Desired Fertility Measures for Wives and Husbands Predict Subsequent Fertility? Evidence from Malaysia. Asia-Pacific Population Journal, 2003, roč. 18, č. 4, s. 5-24. ISSN: 0259-238X.

DAWKINS, Richard. The Selfish Gene. New York: Oxford University Press: New York City. 1976. 224 s. ISBN 0-19-286092-5.

EATON, Joseph W.; MEYER, Albert. Man's Capacity to Reproduce: A Demography of a Unique Population. Glencoe, Illinois: The Free Press, 1954. 59 s. ASIN: B0007DOWZE.

FLEGR, Jaroslav. Úvod do evoluční biologie. Praha: Academia, 2007. 544 stran. ISBN: 80-200-1539-6.

FUČÍK, Petr; CHROMKOVÁ MANEA, Beatrice-Elena. V rozporu, či jednotní? Postoje párů k opatřením prorodinné politiky v ČR. Sociálni studia. 2008, roč. 5, č. 2, s. 69-87. ISSN 1214-813X.

GNOTH, C.; FRANK-HERRMANN, P.; FREUNDL, G.; GODEHARDT, D.; GODEHARDT, E. Time to Pregnancy: Results of the German Prospective Study and Impact on the Management of Infertility. Human Reproduction, 2009, roč. 18, č. 9, s. 1959-1966. ISSN: 1460-2350.

GREENE, Margaret E.; BIDDLECOM Ann E. Absent and Problematic Men: Demographic Accounts of Male Reproductive Roles. Population and Development Review, 2000, roč. 26. č. 1, s. 81-115. ISSN: 0098-7921.

GOLDSCHEIDER, Frances K.; KAUFMAN, Gayle. Fertility and Commitment: Bringing Men Back in. In CASTERLINE, J., LEE, R. (eds.) Fertility in the United States: New Patterns, New Theories. Population and Development Review, 1996. Special Supplement to Vol. 22, s. 87-99. ISSN: 0098-7921.

HOFFMANN-NOWOTNY, H-J. The Future of the Family. In European Population Conference, Helsinki 1987. Plenaries, IUSSP, Central Statistical Office of Finland, Helsinky. S. 113-200.

CHROMKOVÁ MANEA, Beatrice-Elena; FUČÍK, Petr. Teorie konfliktních preferencí a plodnost v České republice. Demografie - revue pro výzkum populačního vývoje, 2007, roč. 49, č. 4, s. 244-252. ISSN 0011-8265.

JENSEN, Tina K. a kol. Regional Differences in Waiting Time to Pregnancy among Fertile Couples from Four European Cities. Human Reproduction, 2001, roč. 16, č. 12, s. 2697-2704. ISSN: 1460-2350.

LESTHAEGHE, Ron. The Second Demographic Transition in Western Countries: An Interpretation. In MASON, K. O., JENSEN, A. M. (eds.) Gender and Family Change in Industrialized Countries. New York: Oxford University Press, 1995, s. 7-62. ISBN: 0198289707.

KEYFITZ, Nathan. The Family That Does Not Reproduce Itself. Population and Development Review, 1986, roč. 12, Supplement: Below-Replacement Fertility in Industrial Societies: Causes, Consequences, Policies, s. 139-154. ISSN: 0098-7921.

MORGAN, S. Philip; RACKIN, Heather. The Correspondence of Fertility Intentions and Behavior in the U.S. Population and Development Review, 2010, roč. 36, č. 1, s. 91-118. ISSN: 0098-7921.

OPPENHEIMER, Valerie Kincade. A Theory of Marriage Timing. American Journal of Sociology, 1988, roč. 94, č. 3, s. 563-591. ISSN: 00029602.

PAGET, W. John; TIMAEUS, Ian M. A Relational Gompertz Model of Male Fertility Development and Assessment. Population Studies, 1994, roč. 48, č. 2, s. 333-340. ISSN: 00324728. 
RENDALL, Michael S.; CLARKE, Lynda H.; PETERS, Elizabeth; RANJIT, Nalini; VERROPOULOU, Georgia. Incomplete Reporting of Men's Fertility in the US and Britain: A Research Note. Demography, 1999, roč. 36, č. 1, s. 135-144. ISSN: 1533-7790.

ROTKIRCH, Anna; BASTEN, Stuart. Men Longing for Children: Social and Situational Characteristics. Video Conference From Intentions to Behaviour: Reproductive Decision-Making in a Macro-Micro Perspective. 2010.

SHRYOCK, Hanry S.; SIEGEL, Jacob S. a kol. The Methods and Materials of Demography. San Diego, CA: Academic Press, 1976. 577 s.

SONENSTEIN, Freya L.; STEWART, Kellie; DUBERSTEIN LINDBERG, Laura; PERNAS, Marta; WILlIAMS, Sean. Involving Males in Preventing Teen Pregnancy: A Guide For Program Planners. Advice and Strategies from Successful Programs that Teach Young Men about Responsible Sexual Behavior. Washington, D.C.: Urban Institute. 1997, $176 \mathrm{~s}$.

STONE, Lawrence. The Family, Sex and Marriage in England 1500-1800. London: Penguin Books (paperback), 1979. 293 s. ISBN: 019822401X.

THOMSON, Elisabeth. Couple Childbearing Desires, Intentions, and Births. Demography, 1997, roč. 34, č. 3, s. 343-354. ISSN: 00703370.

THOMSON, Elisabeth; HOEM, Jan M. Couple Childbearing Plans and Births in Sweden. Demography, 1998, roč. 35, č. 3, s. 315-322. ISSN: 00703370.

TÖLKE, Angelika; DIEWALD, Martin. Insecurities in Employment and Occupational Careers and their Impact on the Transition to Fatherhood in Western Germany. Demographic Research, 2003, roč. 9, č. 3, s. 41-68. DOI: 10.4054/DemRes.2003.9.3.

TOULEMON, Laurent. Men's Fertility and Family Size as Compared to Women's. XXIVth IUSSP General Population Conference Session S-13. 2001.

Van de KAA, Dick J. Europe's Second Demographic Transition. Population Bulletin. Washington: Population Reference Bureau, 1987, roč. 42, č. 1. ISSN: 0032-468X.

Van de KAA, Dick J. The Second Demographic Transition Revisited: Theories and Expectations. In BEETS, G. C. N. a kol. (eds.) Population and Family in the Low Countries 1993. (Updated and abbreviated version of PDOD Werkstukken No. 109, 1988.) Lisse, Zwets and Zeitlinger, NIDI/ CBGS Publication, 1994, č. 30, s. 81-126. ISBN: 90-265-1395-X.

Van de KAA, Dick J. Options and Sequences: Europe's Demographic Patterns. Journal of the Australian Population Association, 1997, roč. 14, č. 1, s. 1-30, ISSN: 0814-5725.

VÍTEČKOVÁ, Miluše. Rodičovství v nesezdaném soužití. In CHALOUPKOVÁ, J. Proměny rodinných a profesnich starti̊. Praha: SOÚ, 2010, s. 117-150. ISBN 978-80-7330-185-9.

VOAS, David. Coflicting Preferences: A Reason Fertility Tends to Be Too High or Too Low. Population and Development Review, 2003, roč. 29, č. 4, s. 627-646. ISSN: 0098-7921.

Vývoj obyvatelstva České republiky v roce 2010. 2011. Český statistický úřad: Praha. Publikace e-4007-11.

WESTOFF, Charles F.; RYDER, Norman B. The Contraceptive Revolution. Princeton, N.J.: Princeton University Press, 1977. 397 s. ISBN: 078379438X.

WESTOFF, Charles F. Fertility Decline in the West: Causes and Prospects. Population and Development Review, 1983, roč. 9, č. 1, s. 99-104. ISSN: 0098-7921.

WEISS, Petr; ZVĚǨINA, Jaroslav. Sexuální chování české populace. Urologie pro praxi, 2009, roč. 10, č. 3, s. 160-163, ISSN: 1803-5299.

ZHANG, Li. Male Fertility Patterns and Determinants. Dordrecht: Springer, 2011. 206 s. ISBN: $978-$ 90-481-8939-7. 


\section{Autor a autorka}

Ladislav Rabušic je profesorem katedry sociologie FSS MU a ředitelem Ústavu populačních studií FSS MU. Svůj badatelský zájem soustřed’uje především na problematiku populačních studií v kontextu společenských změn a na otázky hodnotových proměn. Je autorem desítek statí a řady kapitol v knihách publikovaných jak doma, tak i v zahraničí. Je českým zástupcem v Radě programových ředitelů konsorcia European Values Study.

Kontakt:rabu@fss.muni.cz

Beatrice Chromková Manea působí v Ústavu populačních studií FSS MU jako odborná pracovnice. Zabývá se především tématy týkajícími se reprodukčního chování se zaměřením na muže a rodinné politiky. $\mathrm{K}$ jejím dalším výzkumným zájmům patří oblast sociologie dětství a výzkum s dětmi. Výsledky její práce jsou publikovány v odborných článcích a knihách. Kontakt: manea@fss.muni.cz 